\title{
Biological Management of Damping-0ff, Buckeye Rot and Fusarial Wilt of Tomato (cv. Solan Lalima) under Mid-Hill Conditions of Himachal Pradesh
}

\author{
Nitika Thakur*, Astha Tripathi \\ Department of Microbiology, Shoolini University of Biotechnology and Management Sciences, Bajhol Campus, \\ Solan (Himachal pradesh), India \\ Email: nitikathakur45@gmail.com
}

Received 31 March 2015; accepted 23 May 2015; published 29 May 2015

Copyright (C) 2015 by authors and Scientific Research Publishing Inc.

This work is licensed under the Creative Commons Attribution International License (CC BY). http://creativecommons.org/licenses/by/4.0/

(c) (i) Open Access

\section{Abstract}

Disease management is often complicated by the presence of multiple types of pathogens; in an organic system, it is appropriate to develop disease control strategies. The available literature so far reflects that the management of important disease of tomato is through the integrated approaches and very few organic approaches have been tried with various degree of success. Boiopriming of seeds with biocontrol agents (Trichoderma viridae, Trichoderma harzianum and Pseudomonas fluorescens) in combination with different biofertilizers (Azotobacter, Azospirillum and PSB) and organic manures (FYM and vermi-compost) were tested against disease incidence and health management of tomato seedling under nursery as well as field conditions. The studies were conducted during two successive years (2012-2013) at farmer's field with the objective to combat with the increasing disease incidence of three major disease damping-off, fusarium wilt and buckeye rot from nursery stage to the final harvesting. The study focused on the use of biocontrol agents as the suitable alternative to chemical pesticides with sustainable disease management without pesticide residues in foodstuff. The bio priming of seeds with fungal antagonist Trichoderma viridae and harzianum and bacterial antagonist Pseudomonas fluorescens significantly improved the germination behavior of tomato seeds as compared to untreated control. Highest mean germination (93.1\%) and seedling vigour (953.33) was recorded in Treatment 3 (FYM @ 200 q/ ha + Azospirillum + PSB + Trichoderma herzianum (4 kg/ha each) and lowest in control $(60.3 \%)$ and (304.83), thus indicating a significant per cent increase in seedling emergence $(54.4 \%)$ and seedling vigour (95.23\%). A considerable reduction in disease incidence (pre and post) of damp-

\footnotetext{
${ }^{*}$ Corresponding author.
} 
ing off was observed in treatment $\mathrm{T}_{3}$ and $\mathrm{T}_{4}$ (VC @ $50 \mathrm{q} / \mathrm{ha}+$ Azospirillum + PSB + Trichoderma herzianum @ (4 kg/ha) with $45.6 \%$ and $35.4 \%$ respectively). Treatment $T_{3}$ proved highest in terms of yield $(665 \mathrm{Kg} / \mathrm{Ha})$, Hence these diseases can be managed by successful application of Biocontrol agents.

\section{Keywords}

\section{Biocontrol Agents, Biofertilizers, Disease Incidence, Organic Manure, Tomato, Yield}

\section{Introduction}

Solan lalima is an open pollinated and indeterminate variety of tomato having superiority over the present tomato hybrids available in the markets in terms of fruit quality and productivity. Being open pollinated variety, it's a suitable option for organic cultivation. The farmer can produce its seeds at their own farm. The importance of healthy seed selection and disease free nursery raising is the most important requirement to have the desired crop performance, lower the abiotic and biotic yield limiting constrains, reduce the incidence of insect-pestdisease (IPD) and to fetch remunerative economic return to the farmers. The reduction in potential yield in hills by the farmer is due to the increasing susceptibility of pre and post emergence of insect-pest and diseases at regular intervals, right from the nursery raising to the final harvesting period, where the incidence of most pathogenic diseases like Damping off (Pythium aphanidermatum), bacterial wilt (Ralstonia solani) and fusarial wilt (Fusarium oxysporum) etc. can be witnessed which ruin the crop diversity and quality to the most worst level. The problem becomes more severe when the crop is attacked by the cascade of diseases one after the other. The use of conventional chemical pesticides is considered most preferred practices to manage the outbreaks of these diseases, but the indiscriminate chemical approach to deal with these hazards has contributed to adverse effects like soil acidity, impairing soil physical conditions, reducing beneficial microbial population and continuously degrading organic matter, increasing plant susceptibility to insect-pest-diseases and decreasing soil lives.

The use of biocontrol agents (BCA's) in combination with organic manures and biofertilizers is the suitable alternative to chemical applications with sustainable disease management without pesticides residues in food stuffs, development of resistance in plant pathogens and appearance of new strains of these pathogens. The biocontrol agents are highly effective, inexpensive with excellent shelf life and suitable method of delivery [1]. Tomato is playing an indispensable role in the economic upliftment of hilly area farmers in form of off season crop in the mid hills of Himachal Pradesh. Tomato produced in Himachal Pradesh during June to November becomes off season vegetable in the markets of North Indian plains fetching very remunerative prices to farmers. The area and production of tomato crop in India, H.P. and Solan district is summarized in Table 1.

Determining the burning criteria of food quality and safety concerning each individual, an organic strategy can prove a miracle in increasing crop productivity, managing insect-pest and diseases, lowering pesticide residues an ultimately boosting up the best economic returns to the farmers.

Keeping in view the above raised priorities, the present studies were undertaken to test:

1) The efficacy of different combinations of organic manures, biofertilizers and BCA's for the management of various diseases, so as to integrate it in disease management schedule at farmer's field.

2) To access the effect of the organic treatments on the productivity and incidence of important diseases.

Table 1. The area (Ha) and production (MT) of tomato crop in India, H.P. and Solan district (2011-2012).

\begin{tabular}{cccc}
\hline \multirow{2}{*}{ S.NO. } & \multicolumn{3}{c}{ Production (MT) and area (Ha) } \\
\cline { 2 - 4 } & Country/state/district & Area (Ha) & Production (MT) \\
\hline 1 & India & 479,200 & $8,585,800$ \\
2 & Himachal Pradesh & 9555 & 3.4 \\
3 & Solan & 4298 & 195,900
\end{tabular}




\section{Materials and Methods}

\subsection{Manures and Bio-Fertilizers}

FYM (Farm yard manure), VC (Vermicompost), AZO (Azotobacter), PSB (phosphate solubilizing bacteria), Neem cakes, AZS (Azospirillum), Trichoderma viridae, Trichoderma harzianum, Pseudomonas fluorescens and Asafetida were procured from Poabs Green Biotech Pvt Ltd Palghat (Kerala).

\subsection{Experimental Design and Location}

A field experiment was conducted at farmer's field in basal village of Solan block of HP, during the year 2012-2013. For the studies commercially grown vegetable tomato (solan lalima, organically certified) was selected. The trial was laid using a RBD (Randomized Block design) with three replications. A whole of 7 treatments and 3 replications were worked out. Under organic treatments, no chemical fertilizers and pesticides were used, rather than a combinatorial approach combining the use of organic manures, biofertilizers with addition of biocontrol agents were used. The treatments ranged from $T_{1}$ to $T_{7}$. The detailed descriptions of these treatments are given in Table 2.

All the treatments were comparatively analyzed with respect to production and profitability in terms of technology used for seed treatment, nursery raising, manurial and fertilizers schedule, sowing times and spacing etc.

\subsection{Seed Treatment}

The treatments comprised of seed treatment which included treating seeds with fungal strain Trichoderma viride (Poabs Biotech Pvt. Limited) @ $4 \mathrm{~g} / \mathrm{kg}$ of seeds. The bed size for raising nursery was 1/3 $\mathrm{mtx} 15 \mathrm{~cm}$ flourished with well rotten FYM and VC @ 20 - 25 kg with combination of Pseudomonas fluroscens and Trichoderma herzianum @ 1.0\% as biocontrol agent and PSB as biofertilizers @ 1.5 kg, during the first week of March during both the years.

\subsection{Soil Treatment}

Soil treatment was done by applying a combination of Trichoderma viride with panchagavya/jeeva amrit @ 4 g/L.

\subsection{Seedling Treatment}

The 15 - 20 days old seedling was treated with 7 g/L neem soap spray.

\subsection{Nursery Drenching}

Nursery drenching was done with Pseudomonas fluroscens (10 g/L).

Lastly before transplanting seedlings to the main field they were dipped in suspension solution of asfoetida @ $100 \mathrm{~g} / 5 \mathrm{~L}$ of water for 15 - 20 minutes. The protocol (ICCOA standard protocol) followed in field after trans-

Table 2. The organic treatments with detailed description.

\begin{tabular}{|c|c|}
\hline \multirow{2}{*}{ Treatments } & Treatments designed with detailed description \\
\hline & Detailed description \\
\hline $\mathrm{T}_{1}$ & FYM@200 q/ha + Trichoderma viride@4 kg/ha \\
\hline $\mathrm{T}_{2}$ & VC@50 q/ha +Trichoderma viride@4kg/ha \\
\hline $\mathrm{T}_{3}$ & FYM @ 200 q/ha + Azospirillum + PSB + Trichoderma herzianum (4 kg/ha each) \\
\hline $\mathrm{T}_{4}$ & VC@ 50 q/ha + Azospirillum + PSB + Trichoderma herzianum@ (4kg/ha) \\
\hline $\mathrm{T}_{5}$ & FYM@200 q/ha + Azotobacter + PSB (4 kg/ha) \\
\hline $\mathrm{T}_{6}$ & VC@ 50 q/ha + Azotobacter + PSB (4 kg/ha) \\
\hline $\mathrm{T}_{7}$ (control) & FYM@250 q/ha + chemical fertilizers (CAN@650 kg/ha, urea@) 650 kg/ha + pesticides (40 - 50 no. of sprays) \\
\hline
\end{tabular}


planting seedlings to main field is described in Table 3.

\subsection{Observations}

Observation were recorded on seedling emergence, vigour, incidence of disease (pre and post emergence), yield (Kg/ha) in comparison to an untreated control with reference to following under given parameters [2].

- Seedling emergence $(\%)=$ No. of seedlings emerging out of total germinated.

- Seedling vigour $=$ (germination $\% \mathrm{x}$ seedling length $(\mathrm{cm})$ and $\%$ increase in vigour.

- Incidence of pre emergence rot (\%) was calculated by;

Total number of seeds sown-germinated seeds

- Post emergence rot (\%) was calculated by;

$\%$ of toppled plant out of germinated ones

- Incidence of diseases and reduction in disease: (\%) (Damping off, buckeye rot and fusarial wilt).

Yield (Kg/ha) was recorded in comparison with the control.

\subsection{Statistical Analysis}

The data pertaining to estimation of various parameters was analyzed by Significance tests reported by analysis of variance (ANOVA) at $\mathrm{p}=0.05$ significance level with SPSS STAT 20 Software for (RBD) Randomized Block Design.

Table 3. Protocol followed during cropping period for 2012-2013 (ICCOA-International Competence Center for Organic Agriculture).

\begin{tabular}{|c|c|}
\hline \multicolumn{2}{|r|}{ Protocol followed during Cropping period } \\
\hline Activity & Technological Intervention \\
\hline Plot size & $1100 \mathrm{sqm}$ \\
\hline Preparation of land & Four plouging followed by flanking and final lying out of experimental bed plots. \\
\hline Variety selection & Solan lalima (Open pollinated) \\
\hline Seed source & Procured from Department of Vegetable crops Dr. Y.S. Parmar-UHF Solan \\
\hline Seed rate & $400 \mathrm{~g} / \mathrm{ha}$ \\
\hline Seed treatment & Trichoderma viridae@4g/kg of seed \\
\hline Seed spacing & $5 \mathrm{~cm} \times 2 \mathrm{~cm} \times 0.5 \mathrm{~cm}$ \\
\hline Nursery raising & $\begin{array}{l}\text { Beds of } 1 \mathrm{~m} \times 3 \mathrm{~m} \times 20 \mathrm{~cm} \text { to which FYM @ } 20 \text { - } 25 \mathrm{Kg} / \mathrm{or} \text { VC } 5 \text { - } 6 \text { Kg, Trichoderma } \\
\text { harzianum @ } 4 \mathrm{~g} / \mathrm{Kg} \text { and } 1.2 \mathrm{Kg} \text { neem cakes were incorporated. }\end{array}$ \\
\hline Seedling treatment & $\begin{array}{l}\text { Neem soap spray ( } 7 \mathrm{~g} / \mathrm{l}) \text { to } 15 \text { days old seedlings-Drenching of seedling with Pseudomonas } \\
\text { fluorescens }(10 \mathrm{~g} / \mathrm{L}) \text { before transplanting. Root Dipping of seedlings in solution of } \\
\text { asafetida ( } 100 \mathrm{~g} / 5 \mathrm{~L} \text { water) for } 25 \text { - } 30 \text { minutes before transplanting to the experimental plots. }\end{array}$ \\
\hline Soil fertility management & $\begin{array}{l}\text { Application of organic manures and bio-fertilizers. Mixing of FYM @ } 200 \text { quintal/ha + VC @ } \\
50 \text { quintal/ha + neem cake @ } 250 \text { kg/ha at the time of forming ridges. }\end{array}$ \\
\hline Irrigation requirements & $\begin{array}{l}\text { Two watering, morning and evening for one week. One time watering for second week. } \\
\text { Alternate day watering during third week of transplanting and } 5 \text { - } 7 \text { days interval irrigation } \\
\text { during the cropping period depending upon the weather. }\end{array}$ \\
\hline Weed management & Hand weeding was used. During the entire cropping period three hand weeding was done. \\
\hline Staking & $\begin{array}{l}\text { Bamboo poles having } 8 \text { feet height supported by CGI wires and plastic ropes were used as } \\
\text { support system. }\end{array}$ \\
\hline Crop protection & $\begin{array}{l}\text { Insect pest and disease management was undertaken by using all the organic approaches that is } \\
\text { installation of yellow sticky traps, spray of biopesticides NPV (Nuclear Polyhedrosis virus), } \\
\text { placement of trio card, use of neem cake/neem extract, vermin wash, use of barrier crops and } \\
\text { other bio control agents(Trichoderma herzianum-10 g/l of water), Pseudomonas flourescens (10 } \\
\text { g/l of water). }\end{array}$ \\
\hline
\end{tabular}




\section{Results}

The results obtained are presented and discussed under the following headings:

\subsection{Nursery Trials}

The nursery stage was set up with six designed organic treatments against an untreated control (farmers practice $\mathrm{T}_{7}$ ) (Figure 1). Treatments $\mathrm{T}_{3}$ (FYM @ 200 q/ha + Azospirillum + PSB + Trichoderma herzianum (4 kg/ha each)) was found to be most effective in all aspects of studies as stated under succeeding headings:

\section{Seedling Emergence and Vigour Index}

Biopriming of tomato seeds with Trichoderma isolates (T. viridae and T. herzianum) and bacterial antagonist ( $P$. fluorescens) in combination with devised organic treatments improved the seed germination \% and seedling vigour index to a significant level $(\mathrm{p}=0.05)$. Highest mean germination $(93.1 \%)$ was recorded in treatment $\mathrm{T}_{3}$ (Table 4(a)) with a vigour index of 953.33, followed by $\mathrm{T}_{2}(89.4 \%$ and $767.7 \%)$ and $\mathrm{T}_{4}(85.8 \%$ and $813.6 \%)$ respectively, resulting in an maximum increase of $54.4 \%$ in seed emergence and 95.23 in seedling vigour index over untreated control. Thus there was significant increase (Figure 2$)$ at $(p=0.05)$ in root length $(p=0.01)$, shoot length $(\mathrm{p}=0.01)$, no. of roots and internodal length $(\mathrm{p}=0.001)$ being highest in treatment $\mathrm{T}_{3}(\mathrm{Table} 4(\mathrm{~b}))$ as compared to an untreated check $\left(T_{7}\right)$ which ultimately enhanced the seedling vigour index $(p=0.01)($ Figure 3).

All the bioformulations proved significantly effective in reducing the pre and post-emergence damping-off disease in tomato nursery compared to an untreated check. Maximum mean reduction (45.6\%) in pre emergence rots while $58 \%$ reduction in post emergence rots with treatment $\mathrm{T}_{3}$ was recorded. $\mathrm{T}_{4}$ and $\mathrm{T}_{2}$ were at par with $35.4 \%$ reduction in pre emergence disease incidence and $59 \%$ and $39.3 \%$ post emergence disease reduction as compared to untreated control. From the data presented in Table 5, it is inferred that bioagents were found to be more effective in checking the post emergence rots where the disease incidence was reduced to a broader level (59\%) as compared to pre emergence rot reduction level (45.6\%). All the parameters were significantly increased $(\mathrm{p}=0.01)$ at $\mathrm{p}=0.05$.

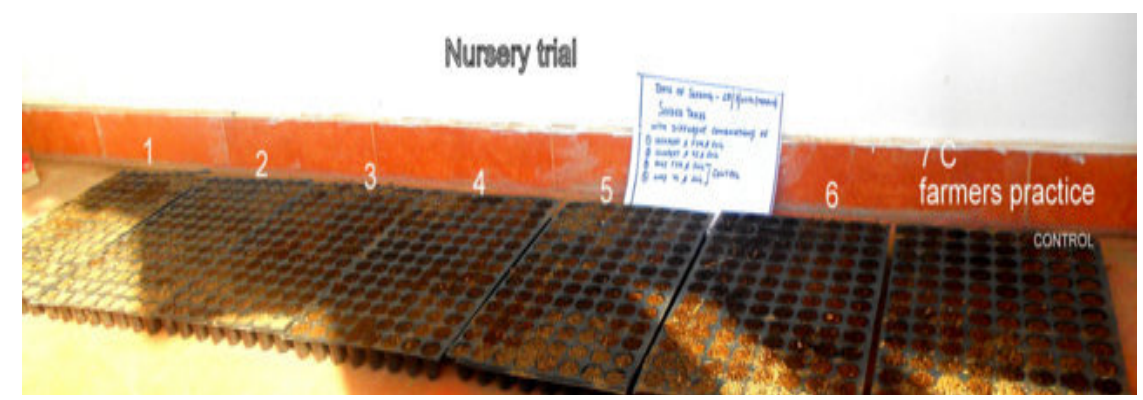

Figure 1. Nursery set up showing six organic treatments and farmers practice (control).

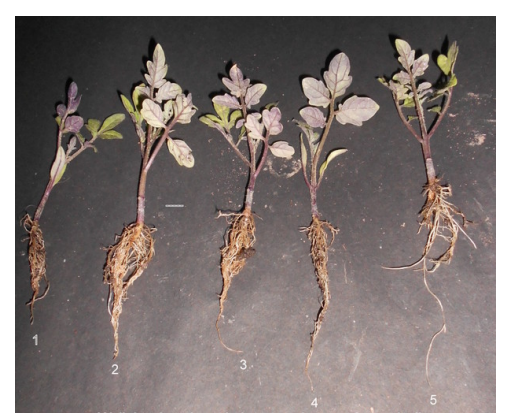

Figure 2. Effect of seed priming with different combinations of organic treatments coupled with BCA's on root length, shoot length, no. of roots and intermodal length of tomato cv. Solan lalima indicating the best treatment $T_{3}$ with increased root length, shoot length, no. of leaves and internodal length. 


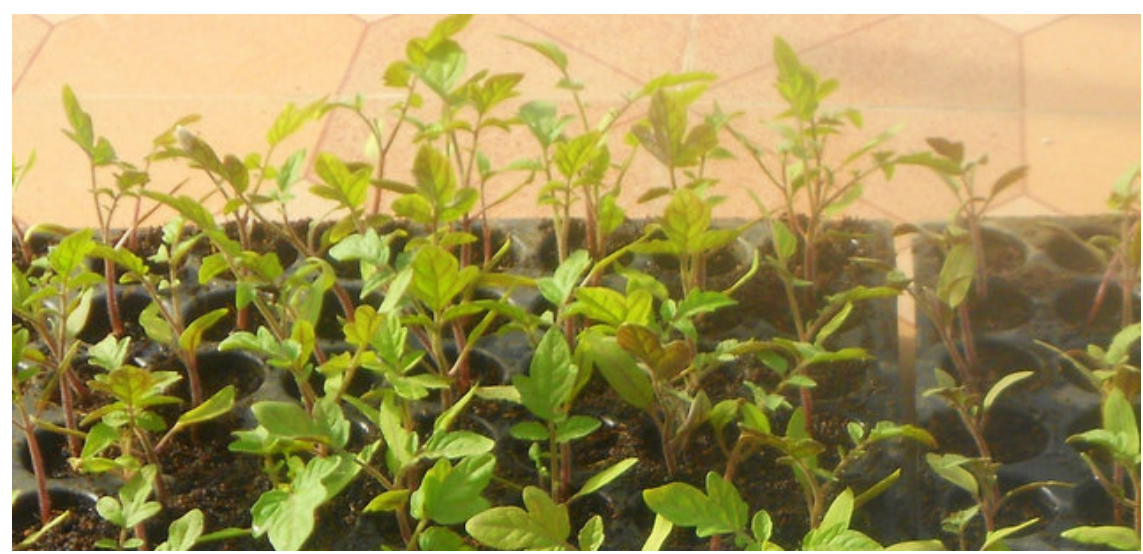

Figure 3. Enhanced tomato seedling vigour and seedling emergence in $\mathrm{T}_{3}$ organic treatment.

Table 4. (a). Effect of seed priming with different combinations of organic treatments coupled with BCA's on germination \% and Seedling vigour index of tomato cv. Solan lalima. (b). Effect of seed priming with different combinations of organic treatments coupled with BCA's on root length and shoots length, no. of roots and internodal length of tomato (cv. Solan lalima).

(a)

\begin{tabular}{ccccc}
\hline \multirow{2}{*}{ Treatments } & \multicolumn{3}{c}{ (Mea \pm SD) Data indicating the seedling germination (\%) and vigor (\%) (2012-2013) } \\
\cline { 2 - 5 } & * Seedling germination (\%) & *Seedling vigor (\%) & Increase in seedling germination and vigor over control (\%) \\
\hline $\mathrm{T}_{1}$ & $72.36 \pm 2.8$ & $532.0 \pm 16.9$ & 19.9 & 74.7 \\
$\mathrm{~T}_{2}$ & $89.49 \pm 0.3$ & $767.7 \pm 16.3$ & 48.3 & 76.6 \\
$\mathrm{~T}_{3}$ & $93.15 \pm 0.3$ & $953.3 \pm 19.0$ & 54.4 & 95.2 \\
$\mathrm{~T}_{4}$ & $85.40 \pm 1.8$ & $813.6 \pm 9.8$ & 41.6 & 81.2 \\
$\mathrm{~T}_{5}$ & $86.30 \pm 0.7$ & $716.12 \pm 18.2$ & 43.1 & 71.5 \\
$\mathrm{~T}_{6}$ & $76.11 \pm 0.0$ & $615.58 \pm 12.8$ & 26.2 & 0.0 \\
$\mathrm{~T}_{7}$ (Control) & $60.33 \pm 1.6$ & $304.8 \pm 17.3$ & 0.0 & 0.0 \\
$\alpha=0.05$ & 0.01 & 0.01 & & \\
Sig. & HS & HS & & \\
\hline
\end{tabular}

SD: standard deviation; Level of significance (at $\alpha=0.05$ by Fisher (F) test; Sig.-significance: $\mathrm{HS}^{* * *}=$ highly significant, best treatments bold and highlighted and control values highlighted but not bold, " data pooled for two consective years (2012-2013).

(b)

\begin{tabular}{ccccc}
\hline \multirow{2}{*}{ Treatments } & \multicolumn{4}{c}{ Data (Mean \pm SD) For Nursery growth parameters (2012-13) } \\
\cline { 2 - 5 } & * Root length $(\mathrm{cm})$ & * Stem length $(\mathrm{cm})$ & * Internodal length(cm) & * Number of roots (no.) \\
\hline $\mathrm{T}_{1}$ & $5.56 \pm 0.1$ & $4.70 \pm 0.1$ & $1.48 \pm 0.0$ & $19.83 \pm 0.8$ \\
$\mathrm{~T}_{2}$ & $5.73 \pm 0.1$ & $5.69 \pm 0.1$ & $1.61 \pm 0.0$ & $43.33 \pm 1.6$ \\
$\mathrm{~T}_{3}$ & $6.48 \pm 0.2$ & $7.13 \pm 0.1$ & $2.71 \pm 0.0$ & $24.44 \pm 0.8$ \\
$\mathrm{~T}_{4}$ & $6.04 \pm 0.1$ & $6.48 \pm 0.1$ & $2.46 \pm 0.0$ & $23.16 \pm 0.7$ \\
$\mathrm{~T}_{5}$ & $5.70 \pm 0.2$ & $6.20 \pm 0.2$ & $2.30 \pm 0.1$ & $22.99 \pm 0.5$ \\
$\mathrm{~T}_{6}$ & $5.50 \pm 0.2$ & $5.33 \pm 0.1$ & $2.44 \pm 0.0$ & $21.50 \pm 0.3$ \\
$\mathrm{~T}_{7}$ (Control) & $2.96 \pm 0.0$ & $3.63 \pm 0.1$ & $1.01 \pm 0.0$ & $10.66 \pm 0.5$ \\
$\alpha=0.05$ & 0.01 & 0.01 & 0.01 & 0.01 \\
Sig. & $\mathrm{S}^{* *}$ & $\mathrm{~S}^{* *}$ & $\mathrm{~S}^{* *}$ & $\mathrm{HS}^{* * *}$ \\
\hline
\end{tabular}

SD: standard deviation; Level of significance (at $\alpha=0.05$ by Fisher (F) test; Sig.-significance: HS ${ }^{* * *}=$ highly significant, best treatments bold and highlighted and control values highlighted but not bold, * data pooled for two consective years (2012-2013). 
Table 5. Effect of seed priming with different combinations of organic treatments coupled with BCA's on disease incidence \% of damping-off (pre and post seedling emergence) in nursery trials of tomato cv. Solan lalima.

\begin{tabular}{|c|c|c|c|c|}
\hline \multirow{3}{*}{$\begin{array}{c}\text { Treatments } \\
\qquad \mathrm{T}_{1}\end{array}$} & \multicolumn{4}{|c|}{ Pre and post-damping off disease at nursery stage } \\
\hline & \multicolumn{2}{|c|}{ Pre damping-off RDI (\%) } & \multirow{2}{*}{$\begin{array}{c}\text { Post-damping off } \\
24.0 \pm 1.7\end{array}$} & \multirow{2}{*}{$\begin{array}{c}\text { RDI (\%) } \\
46\end{array}$} \\
\hline & $40.9 \pm 1.2$ & 29.6 & & \\
\hline $\mathrm{T}_{2}$ & $37.5 \pm 0.7$ & 35.4 & $27.3 \pm 3.6$ & 39.3 \\
\hline $\mathrm{T}_{3}$ & $31.6 \pm 1.3$ & 45.6 & $18.7 \pm 3.0$ & 58 \\
\hline $\mathrm{T}_{4}$ & $42.9 \pm 3.2$ & 35.4 & $18.2 \pm 4.0$ & 59 \\
\hline $\mathrm{T}_{5}$ & 44. $1 \pm 5.6$ & 31.7 & $28.8 \pm 3.4$ & 36 \\
\hline $\mathrm{T}_{6}$ & $40.8 \pm 8.2$ & 29.7 & $29.7 \pm 9.5$ & 34 \\
\hline $\mathrm{T}_{7}$ (Control) & $58.1 \pm 2.6$ & 0.0 & $45.0 \pm 2.3$ & 0.0 \\
\hline$\alpha=0.05$ & 0.01 & & 0.01 & \\
\hline Sig. & $\mathrm{HS}^{* * *}$ & & $\mathrm{HS}^{* * *}$ & \\
\hline
\end{tabular}

SD: standard deviation; Level of significance (at $\alpha=0.05$ by Fisher (F) test; Sig.-significance: HS ${ }^{* * *}=$ highly significant, best treatments bold and highlighted and control values highlighted but not bold, * data pooled for two consective years (2012-2013). RDI-reduction in disease incidence.

\subsection{Field Trials}

The healthy nursery when transferred to field (Figure 4) resulted in considerable reduction in disease incidence and thus healthy tomato fruits were obtained with organically designed treatments as compared to farmers practice (control) as listed under following sub headings.

\section{Survival Percentage of Seedlings in Field}

The inferences drawn from Table 6 revealed about the total successful emergence of tomato seedlings and percent reduction in disease incidence of fusarial wilt and buckeye rot (Figure 5) after transplanting to a main field. The results indicated that mean germination (81\%) was reported in $\mathrm{T}_{3}$, followed by $73.1 \%$ in $\mathrm{T}_{5}$, respectively compared to control (59.5\%).

However, the mean reduction in fusarial wilt and buckeye rot was found to be $47.4 \%$ and $38 \%$ under treatment $\mathrm{T}_{3}$, indicating a considerable significant $(\mathrm{p}=0.01)$ reduction in fusarial wilt and buckeye rot. The mean highest yield (Figure 6) was recorded in treatment $\mathrm{T}_{4}(665 \mathrm{Kg} / \mathrm{ha})$ over an untreated check (Figure 7) (649.5 $\mathrm{Kg} / \mathrm{ha}$ ) (Table 7).

\section{Discussion}

All botanicals were found significantly effective in increasing the seedling emergence and vigour index of tomato seeds under both nursery and field conditions. Similar findings on testing biocontrol agent's effectiveness against disease control, improvement in seedling vigour, seedling emergence were worked out in cauliflower [3] in capsicum, in tomato [4]. The results were at par with the work, where the use of Trichoderma isolates and bacterial antagonists used for biopriming of tomato seeds resulted in improvement in seed emergence (\%), vigour (\%) and biomass. The significant increase in the parameters (root length, shoot length, no. of roots and internodal length) resulted from the inherent capacity of bioagents which have been observed to protect the seeds from diseases as well as providing nutrients to germinating seeds by decomposition of organic matter. Secretion of hormones and release of nutrients from soil organic matter have been proposed as a mechanism involved in plant growth promotion [5] [6]. It is inferred that bioagents seem to be more effective in checking the post emergence rots where disease incidence is reduced to a broader level (59\%) as compared to pre emergence rot reduction level (45.6\%). The results of the studies are in consence with the findings of [7] where a similar inference was drawn with maximum disease reduction in post emergence rot incidence compared to pre rot incidence, due to the time required for multiplication of inoculum of bioagents in rhizosphere and collar region of seedling. Similar control of damping off has been observed through application of Trichoderma viridae and 


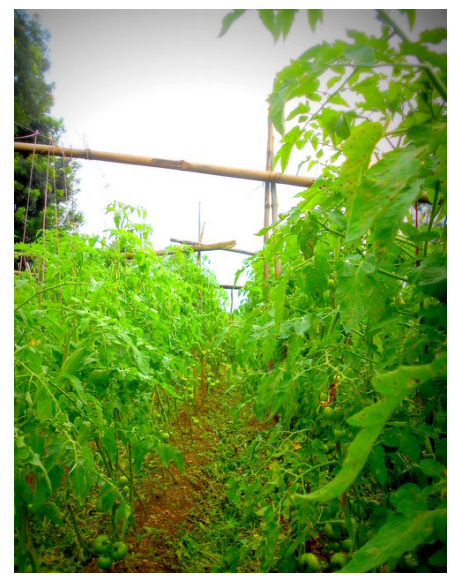

Figure 4. Field trials showing healthy organic seedlings transferred to field.

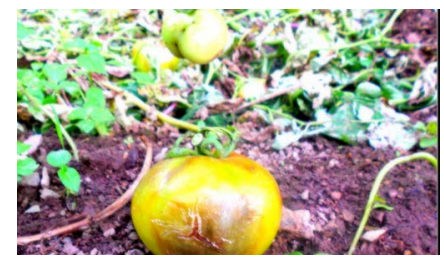

Figure 5. Diseased Tomato fruit showing buckeye rot.

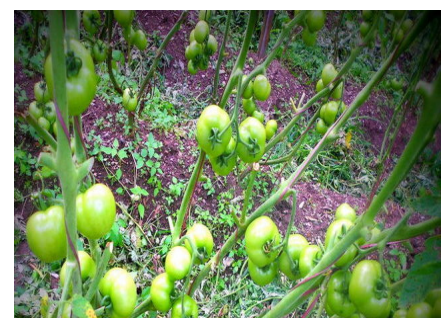

Figure 6. Tomato fruit yield (Kg/ha) under Conventional cultivation.

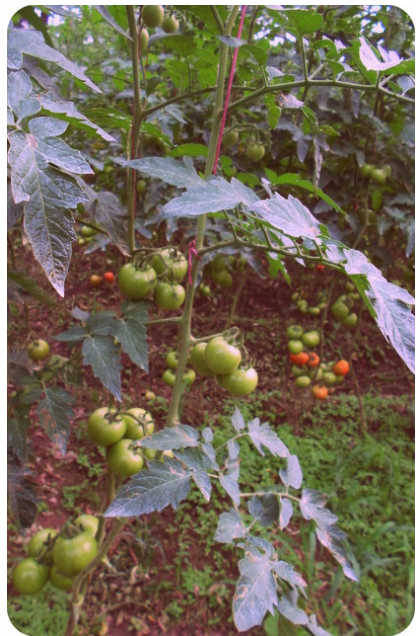

Figure 7. Tomato fruit yield (Kg/ha) under Conventional cultivation. 
Table 6. Effect of seed priming with different combinations of organic treatments coupled with BCA's on germination, percent disease incidence and reduction in disease incidence of fusarial wilt and buckeye rot.

\begin{tabular}{cccccc}
\hline \multirow{2}{*}{ Treatments } & \multicolumn{5}{c}{ Field trial results: pooled (Mean \pm SD) data of two years (2012-2013) } \\
\cline { 2 - 5 } & Germination\% & Fusarial wilt\% & RDI\% & Buckeye rot \% & RDI \% \\
\hline $\mathrm{T}_{1}$ & $74.35 \pm 2.2$ & $40.3 \pm 3.4$ & 43.2 & $54.3 \pm 1.2$ & 19.6 \\
$\mathrm{~T}_{2}$ & $6.96 \pm 5.0$ & $41.9 \pm 2.6$ & 40.9 & $51.9 \pm 0.3$ & 23.2 \\
$\mathrm{~T}_{3}$ & $81.0 \pm 2.1$ & $37.3 \pm 1.3$ & 47.4 & $41.9 \pm 3.2$ & 38.0 \\
$\mathrm{~T}_{4}$ & $71.1 \pm 3.1$ & $46.2 \pm 1.4$ & 34.9 & $46.1 \pm 1.5$ & 31.8 \\
$\mathrm{~T}_{5}$ & $73.1 \pm 2.0$ & $41.8 \pm 6.5$ & 41.1 & $52.3 \pm 0.8$ & 22.6 \\
$\mathrm{~T}_{6}$ & $69.8 \pm 2.25$ & $43.2 \pm 2.8$ & 39.1 & $50.8 \pm 0.6$ & 24.8 \\
$\mathrm{~T}_{7}$ (control) & $59.5 \pm 2.8$ & $71.0 \pm 2.3$ & 0.0 & $67.6 \pm 3.2$ & 0.0 \\
$\alpha=0.05$ & 0.01 & 0.01 & & 0.01 & HS \\
Sig. & HS $^{* * *}$ & $\mathrm{HS}^{* * *}$ & & \\
\hline
\end{tabular}

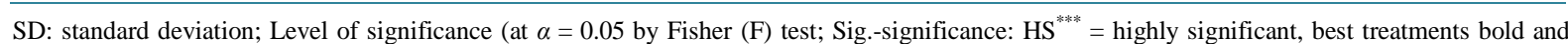
highlighted and control values highlighted but not bold, " data pooled for two consective years (2012-2013). RDI: reduction in disease incidence.

Table 7. Effect of seed priming with different combinations of organic treatments coupled with BCA's on yield of tomato.

\begin{tabular}{|c|c|c|c|}
\hline \multirow{2}{*}{ Treatments } & \multicolumn{3}{|c|}{ Yield (Kg/ha)—2012-2013 } \\
\hline & Yield (Kg/ha) & & \\
\hline & $1^{\text {st }}$ Year & $2^{\text {nd }}$ year & Mean \pm SD \\
\hline $\mathrm{T}_{1}$ & $591.3 \pm 1.1$ & $608.0 \pm 10.5$ & $599.6 \pm 5.8$ \\
\hline $\mathrm{T}_{2}$ & $589.0 \pm 1.0$ & $620.0 \pm 0.0$ & $604.5 \pm 1.0$ \\
\hline $\mathrm{T}_{3}$ & $621.0 \pm 1.0$ & $643.3 \pm 2.8$ & $632.1 \pm 1.9$ \\
\hline $\mathrm{T}_{4}$ & $614.6 \pm 0.5$ & $716.6 \pm 28.8$ & $665.0 \pm 14.6$ \\
\hline $\mathrm{T}_{5}$ & $610.6 \pm 0.5$ & $675.0 \pm 0.0$ & $642.8 \pm 0.5$ \\
\hline $\mathrm{T}_{6}$ & $611.6 \pm 0.5$ & $640.0 \pm 0.0$ & $635.8 \pm 0.5$ \\
\hline $\mathrm{T}_{7}$ (control) & $639.0 \pm 1.0$ & $660.0 \pm 0.0$ & $649.5 \pm 1.0$ \\
\hline$\alpha=0.05$ & 0.01 & 0.01 & \\
\hline Sig. & $\mathrm{S}^{* *}$ & $\mathrm{HS}^{* * *}$ & \\
\hline
\end{tabular}

SD: standard deviation; Level of significance (at $\alpha=0.05$ by Fisher (F) test; Sig.-significance: HS ${ }^{* * *}=$ highly significant, best treatments bold and highlighted and control values highlighted but not bold, * data pooled for two consective years (2012-2013).

Pseudomonas fluorescence [8] [9]. The study resulted in successive control of daming-off as likewise observed by Kabdal et al., (2010) in his findings and study for health management of capsicum nursery with the use of biocontrol agents. The total successful emergence of tomato seedlings and percent reduction in disease incidence of fusarial wilt and buckeye rot after transplanting to a main field indicated that maximum mean germination was reported in $\mathrm{T}_{3}$, compared to control (64.3\%) and the mean reduction in fusarial wilt and buckeye rot was found to be $63.2 \%$ and $42.3 \%$. The present results are at par with the similar findings [10] where the application of antagonist fungus, Trichoderma as seed and soil treatment agent had significant effect in reducing disease incidence and increasing percent increase in yield over control, according to which simultaneous application of Trichoderma as seed priming and soil incorporation results in protective cover in the seed coat by rapid multiplication and boosting a greater strength to out compete the pathogens.

\section{Conclusion}

In the present investigation the combinatorial approach of integrating biocontrol agents in organic treatments 
gave promising results for increasing the tomato germination (\%) and seedling vigour under both nursery and field conditions, thus reducing the level of three major diseases-damping-off, fusarial wilt and buckeye rot and other harmful pathogens. The addition of microbial biocontrol agents during biopriming allows for colonization of the seed prior to planting and adds a new dimension to seed priming treatments, thus replacing the harmful synthetic fungicides which ruin the whole crop. The implication of the study is to control seed and soil borne pathogens with an application of biocontrol agents coupled with organic manures and biofertilizers right at prime nursery stage so that the incidence of diseases is reduced to a significant level so that it greatly lowers when the tomato seedlings are transplanted in main field, which in turn will help in maximum seedling survival and reduction in disease incidence.

\section{References}

[1] Someshwar, B., Bambawale, O.M., Tripathi, A.K., Ahmad, I. and Srivastava, R.C. (2013) Biological Management of Fusarial Wilt of Tomato by Trichoderma spp. in Andamans. Indian Journal of Horticulture, 70, 397-403.

[2] Kabdal, P., Hooda, K.S., Joshi, D., Hedau, N.K. and Pandey, K.N. (2010) Biocontrol Agents in the Health Management of Capsicum Nursery. Indian Journal of Horticulture, 67, 70-72.

[3] Sharma, P. and Sain, S.K. (2005) Use of Biotic Agents and Abiotic Compounds against Damping off of Cauliflower Caused by Pythium aphanidermatum. Indian Journal of Phytopathology, 58, 395-401.

[4] Pietr, S.J., Wojtkowiak, E., Slusarski, C., Stankiewicz, M., Lewicka, T., Biesiada, A., Elad, Y., (ed.), Kohl, J. (ed.) and Shtienberg, D. (2002) The Possible Systemic Induction of Resistance in Some Vegetables by Fungicide Resistant Trichoderma Isolates. Proceedings of the 7th Working Group Meeting, "Influence of Abiotic and Biotic Factors on Biocontrol Agents at Pine Bay, Kusadasi, Turkey”, 22-25 May 2002. Bulletin-OIL-SROP. 25, 10, 331.

[5] Windham, M.T., Elad, Y. and Baker, R. (1986) A Mechanism for Increased Plant Growth Induced by Trichoderma spp. Phytopathology, 76, 518-521. http://dx.doi.org/10.1094/Phyto-76-518.

[6] Kleifeld, O. and Chet, I. (1992) Trichoderma harzianum - Interaction with Plants and Effect on Growth Response. Plant Soil, 144, 267-272. http://dx.doi.org/10.1007/BF00012884

[7] 7Hooda, K.S., Bhatt, J.C., Joshi, D., Sushil, S.N. and Gupta, H.S. (2008) Biocontrol Agent's vis-à-vis Fungicides in Managing Various Diseases of Tomato (Lycopersicon esculentum Mill.) in Hills of Uttarakhand. Indian Journal of Phytopathology, 61, 331-336.

[8] Manorangitham, S.K., Preakasam, V. and Rajoppan, A.K. (2001) Biocontrol of Damping off of Tomato Caused by Pythium aphanidermatum. Indian Journal of Phytopathalogy, 54, 59-61.

[9] Ramesh, R. (2004) Management of Damping-Off in Brinjal Using Biocontrol Agents. Journal of Mycology and Plant Pathology, 34, 666-670.

[10] Bunkar, R.N. and Mathur, K. (2001) Integration of Biocontrol Agents and Fungicides for Suppression of Dry Rot Root of Capsicum Frutescens. Journal of Mycology and Plant Pathology, 31, 33-34. 